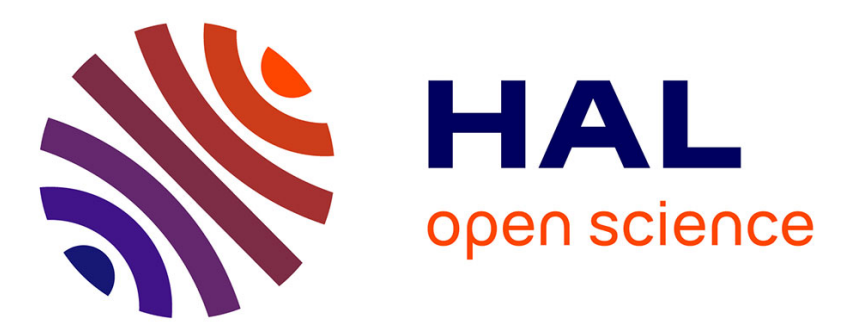

\title{
Highlights from the 8th International Conference on Predictive Modelling in Food (ICPMF8)
}

Mariem Ellouze, Fanny Tenenhaus-Aziza, Frederic F. Carlin

\section{To cite this version:}

Mariem Ellouze, Fanny Tenenhaus-Aziza, Frederic F. Carlin. Highlights from the 8th International Conference on Predictive Modelling in Food (ICPMF8). Food Microbiology, 2015, 45, pp.160-161. 10.1016/j.fm.2014.11.002 . hal-02631954

\section{HAL Id: hal-02631954 \\ https://hal.inrae.fr/hal-02631954}

Submitted on 27 May 2020

HAL is a multi-disciplinary open access archive for the deposit and dissemination of scientific research documents, whether they are published or not. The documents may come from teaching and research institutions in France or abroad, or from public or private research centers.
L'archive ouverte pluridisciplinaire HAL, est destinée au dépôt et à la diffusion de documents scientifiques de niveau recherche, publiés ou non, émanant des établissements d'enseignement et de recherche français ou étrangers, des laboratoires publics ou privés.

\section{(1) (1) $\$$}

Distributed under a Creative Commons Attribution - NonCommercial - NoDerivatives| 4.0 


\section{Editorial}

\section{Highlights from the 8th International Conference on Predictive Modelling in Food (ICPMF8)}

The 8th International Conference on Predictive Modelling in Food (ICPMF8) was organized at the Institut Pasteur, Paris, France, from September 16 to 20, 2013, as an initiative from IFIP, the French Institute of Pig and Pork products, the Sym'Previus scientific interest group, and CNIEL, the French Dairy Organization.

Two-hundred and twenty delegates from 30 countries including Belgium, Brazil, China, Denmark, France, Greece, Korea, Netherlands, New Zealand, Turkey, UK and USA attended the conference. The conference gathered students and young scientists (19\% of the ICPMF8 delegates) as well as leading academics and researchers (50\%) to discuss with food industry representatives about new advances and practical applications of predictive modelling. The presence of Food Business Operators, technical centers, as well as professional federation representatives (20\% of the ICPMF8 delegates) gave a concrete testimony to government representatives (11\%) from several countries (including US, Canada, New Zealand, the European Union, Belgium, and France) about the food industry concern about food safety and interest in the approaches derived from Predictive Microbiology and risk assessment.

Through a special focus on transfer activities towards food business operators, the conference aimed to bring together all the actors working to improve the food quality and safety and to address the global challenges that predictive modellers and risk assessors are facing in the field. The conference program included 10 plenary oral presentation sessions and 4 poster sessions, which focused on four major topics: Data collection, Predictive models for food quality and safety, Advances in methods \& models in predictive microbiology, and Applications of predictive microbiology for food industry and risk managers. The ICPMF8 program also included:

- a special day dedicated to food business operators with the flagship event of the conference: The Software Fair, during which demonstration sessions were organized for 16 predictive microbiology and risk assessment tools,

- the best poster award student competition supported by ICFMH,

- two pre-conference workshops to discover "Innovative methods in predictive microbiology" and "Risk-based control measures in food establishments",

- one research project seminar on "Modelling processing steps and integration of new factors to control food quality and safety",

- a technical tour to Rungis, the largest fresh produce market in the world.

This paper proposes a summary of the highlights of the conference including invited lectures and significant research works presented at the conference and the most recent advances in the field. In the session dedicated to "Predictive models for food quality and safety", theoretical principles of the models used in Predictive Microbiology (models for growth, survival during thermal and also non-thermal inactivation processes, models describing growth/no growth boundaries, etc.) were presented. These models are now well established in the scientific community to predict the behaviour of spoilage and pathogenic micro-organisms in a large variety of foods and processes for the benefit of food quality and safety. Several applications, such as simulations of the simultaneous growth of pathogens (ex. Listeria monocytogenes, Salmonella) and lactic acid bacteria during the process and storage of cold smoked fish, cheese and dried fermented sausages were presented. Specific models addressing yeasts and moulds as well as bacteria spore germination, or adapted approaches to take into account processes with a high industrial interest (ex. long time-low temperature heat treatments, high pressure or thermo-sonication) were also exposed. Complex and innovative models under development about biofilms dynamics and biofilm recontamination in specific process lines were presented.

In the sessions dedicated to "Data Collection" and "Advances in methods and models in predictive microbiology", the variable behaviour of different strains within species of micro-organisms was accounted for. Many research works thus showed a significant variability in the behaviour of cells observed individually (in particular of cells subjected to stress during food processing). Studies at single-cell levels are increasing and their use requires adapted monitoring and observation methods as well as specific data analysis procedures. Several research groups invested a better understanding of the cellular machinery in their modelling approach and the move towards more mechanistic models was clearly underlined at ICPMF8. System Biology and omics technologies explore genetic and metabolic adaptations of cells exposed to changing environments, which results in modulations of growth rates, extent of latency or survival rates. Moreover, predictive models were traditionally developed with experiments performed in liquid media. However growth in real foods occurs in structured food environments and investigations on these particular aspects require special observation techniques that were also considered at the conference. The next step would be to organize and format these data to make them easily available for the user. Web-based applications were thus presented to facilitate data management and data loading using specific ontologies and linked datasets. With such approaches, and such datasets, models tend to become more and more accurate.

In the session dedicated to the "Application of predictive microbiology for food industry and risk managers", consumer exposures 
Version définitive du manuscrit publiée dans / Final version of the manuscript published in :

Food Microbiology (2015), Vol. 45, p. 160-161, DOI: 10.1016/j.fm.2014.11.002

Journal homepage : http://www.elsevier.com/locate/fm

to several microbiological pathogens and risk assessments along the food pathway, from "farm-to-fork" were presented. These approaches are full part of Quantitative Microbial Risk Assessments and Safety Assessments performed both by public health authorities (for ex. EFSA in the EU or the USDA in the United-States, ANSES in France.) and also by food companies. These aspects have been extensively developed at the conference and were related to a wide range of food products. Risk ranking tools and several decision-support tools were also presented either through the classical conference format or through a dedicated event called "Software Fair" where a demonstration of sixteen software was proposed to ICPMF8 delegates. Several features were demonstrated by the software developers such as (i) databases, (ii) simulators for growth, inactivation or growth no growth boundary predictors, (iii) fitting tools for growth, thermal or non thermal inactivation kinetics, (iv) risk assessment tools and also some specific features. The first versions of some of the presented software were launched nearly 20 years ago, but the high number of presented tools (16) witnesses the persisting interest of the community for the development of reliable decision-support tools to be used by scientists or food business operators.

The discussions held at the conference emphasized the importance of a better understanding of the advantages and limits of modelling approaches, as well as the importance of data collection and results interpretation before using the models to propose safe foods to the consumers and limit food wastes and spoilage worldwide. In fact, the risk-based models previously used by risk assessment agencies are now more and more used by food business operators and sharing common science-based tools to ensure food safety and food security, makes it easier to tackle the major challenges linked to food safety for human kind for the decades to come.

\section{Acknowledgements}

We express our gratitude to ICPMF8 sponsors for their support. We would like to thank the International Committee on Predictive
Modelling in Food members as well as the ICPMF8 scientific committee, the local organization committee and the editors of this Special Issue for their support to ICPMF8, and finally the ICPMF8 delegates for lively and fruitful exchanges.

Mariem Ellouze*

IFIP, French Institute for Pig and Pork Products, Fresh and Processed Meats Department,

7 Avenue du Général de Gaulle, 94704 Maisons Alfort, France

Groupement d'Intérêt Scientifique Sym'Previus, 147 rue de l'Université, F-75007 Paris, France

Fanny Tenenhaus-Aziza

CNIEL, Centre National Interprofessionnel de l'Economie Laitière

(French Dairy Board), Technical and Scientific Department, 42 rue du Châteaudun, 75009 Paris, France

INRA, Avignon Université, UMR408 Sécurité et Qualité des Produits d'Origine Végétale, F-84000 Avignon, France

Groupement d'Intérêt Scientifique Sym'Previus, 147 rue de l'Université, F-75007 Paris, France E-mail address: ftenenhaus@cniel.com.

Frédéric Carlin

INRA, Avignon Université, UMR408 Sécurité et Qualité des Produits d'Origine Végétale, F-84000 Avignon, France

Groupement d'Intérêt Scientifique Sym'Previus, 147 rue de l'Université, F-75007 Paris, France E-mail address: Frederic.carlin@avignon.inra.fr.

* Corresponding author. IFIP, French Institute for Pig and Pork Products, Fresh and Processed Meats Department, 7 Avenue du Général de Gaulle, 94704 Maisons Alfort, France. E-mail address: mariem.ellouze@ifip.asso.fr (M. Ellouze). 